\title{
Analysis of Problems Existing in the Financial Management in Construction Enterprises
}

\author{
Yuqi Feng*
}

Accounting Institute, Zibo Vocational Institute, Zibo255314, Shandong, China

\begin{abstract}
With the rapid development of China's economy, construction scale is more and more big; the construction enterprises are facing new opportunities for development, while also facing the fierce competition in the industry. Financial management of construction enterprises is an important measure to ensure the sustainable operation of enterprises, play an important role in the enterprise management. Construction enterprises in order to get a space for one person in the market competition, it must take the effective management of financial accounting. In this paper, through the analysis of the existing problems of the financial management of construction enterprises, and puts forward the corresponding improvement measures.
\end{abstract}

Keywords: Construction enterprise, financial accounting, financial management.

\section{INTRODUCTION}

Construction enterprise as a self-financing organization, once set up, should try to improve the economic efficiency of enterprises and market competitiveness [1-4], the only way to survive, will win the market competitive advantage, but also to be able to continue to grow. If you want to survive, the construction enterprises in the fierce competition in the market economy development and growth [5-9], we must pay attention to the financial and accounting management to improve economic efficiency.

\section{THE MEANING OF FINANCIAL ACCOUNTING}

Financial accounting is a combination of Finance and accounting, finance generally refers to financial activities and financial relations, is refers to the enterprise in the production process of the movement of capital, it is the enterprise and all aspects of the relationship, but also engaged in financial work; accounting is based on the currency as the main units of measurement [10-13], using a series of specific methods, the program of system, continuous, comprehensive accounting and supervision of financial transactions or events, provide financial information, a kind of management activity in the prediction and decision-making, but also refers to the personnel engaged in accounting work.

Financial accounting to provide information for the enterprise outside, it is mainly to the enterprises as the object, must comply with the generally accepted accounting standards and accounting system, to ensure the consistency, comparability of the financial information provided by it; in accounting $[14,15]$, financial accounting to reflect the focus of the data in the past, so the computing requirements clearly and accurately on the accounting information in the financial accounting numbers, the time span is relatively stable; in responsibility, financial accounting information is a formal report, and bear the legal responsibility for reporting.

\section{THE IMPORTANCE TO STRENGTHEN THE FI- NANCIAL MANAGEMENT OF CONSTRUCTION ENTERPRISES}

It is the need of the development of market economy in china. With the rapid development of China's market economy, the increasingly fierce market competition, coupled with a diversified investment main body, the capital market to obtain the full development. Construction units in order not to be defeated rival, a firm foothold in the industry, we should strengthen the management of all aspects of. Diversification of investment subjects, the competitors (investors) to get more financial information, so the construction enterprise should strengthen their own financial and accounting management, to adapt to the development of the socialist market economy, to win in the fierce competition. Is the need of building enterprise competition in the industry. At the present stage, the construction enterprises are facing increasingly fierce competition, in order to survive and develop in the competition, the construction enterprises must change the idea, to change the traditional financial accounting management mechanism, establish a financial and accounting management system suitable for the development of construction enterprises. In the construction enterprise management, financial management is the core of control and management, to adapt to the development requirements of the socialist market economic system. In order to improve the core competitiveness of construction enterprises, and enhance their own development capacity, it is necessary to strengthen the financial management of enterprises. It is the need to maximize the profits of construction enterprises. Construction enterprise is profit oriented economic organization, its starting point and the end result is to make a profit, its essence is to seek for the "shareholder wealth maximization", and the ways to achieve "the shareholder wealth maximization" is to maximize the profit of enterprises. Financial management of 
construction enterprises is arising in management of financial activities and financial relations based on, is relevant to the capital acquisition and effective use of management tools, is to follow the objective economic laws, in accordance with the laws, regulations and the financial system, in order to improve the enterprise's comprehensive economic benefits for the purpose, the rational organization of the movement of capital, integration the value of correctly handling the relation of finance management. Therefore, the construction enterprise management on financial management as the center, to seek to maximize shareholder wealth is the inevitable requirement of the nature of the firm, at the same time it is scientific development strengthen management requirements of enterprises. Scientific development embodies the world outlook and methodology to guide the development of the theory, is the fundamental policy to guide China's overall economic and social development, and pointed out the direction for the enterprises to improve management, and promote the reform and development. According to the scientific development requirements, construction enterprises to seek development must take the quality and efficiency of development, strengthen enterprise management, improve the means, to improve the level of management, increase economic efficiency; to achieve the maximization of shareholder wealth has become the only choice in front of us.

\section{CONSTRUCTION ENTERPRISES SHOULD CHOOSE THE PROPER FINANCIAL ACCOUNTING MANAGEMENT}

Before the construction enterprises in the financial accounting management operations, the operator and the person in charge of finance should first establish financial and accounting management a reasonable target for the enterprise, with a clear goal, enterprises can have a clear direction, to develop specific implementation plans, to achieve this goal, the realization of an objective to promote the construction enterprises, the rapid, healthy and long-term development. Financial management goal is in the specific financial environment, through the organization of financial activities, financial relationships to achieve the purpose of. Fundamentally speaking, financial objectives depends on the survival of enterprises or enterprise, depends on the specific social economic model. At present, the financial management target is representative of the main enterprise value maximization and profit maximization two. However, the construction enterprises in the financial management objectives and determine the choice, must according to their own needs and requirements of the development to develop, so that it can give full play to the role of financial management goal orientation, constraints and evaluation function, it can guide the enterprise to the scientific direction.

\section{THE STATUS OF FINANCIAL MANAGEMENT OF CONSTRUCTION ENTERPRISES}

\subsection{By the Direct Management of the Past into the Hier- archical Management}

The traditional financial accounting system is issued by the State Ministry of Finance and the people's Construction Bank Chinese below, do everything by rule. After the re- form, the enterprise financial management is divided into the following three parts. The first level: "enterprise financial rules", "enterprise accounting standards". This is the basic regulations of enterprise financial accounting system, is the standard and criterion of the financial sector must be observed. The second level: according to the "enterprise financial rules" established "construction, real estate development enterprise financial system", the so-called enterprise financial system. Third levels: enterprise according to the provisions of the first level and second level, according to the measures for the financial management of enterprise production and management characteristics of the development of the enterprise.

\subsection{Cancel Earmarked Accounts and Savings System in the Management of Funds, the Establishment of Capital System}

"The construction, real estate development enterprise financial system" to break the fixed assets, fixed assets, funds flow, fund flow, special fund special asset, three period balance. In accordance with the "assets = Liabilities + owners' equity balance between" the sources of funds of enterprises, will be divided into two major categories of owner's equity and debt.

\subsection{The Reform of Cost Management System, the Estab- lishment of a Financial Evaluation Index System of the New}

The reform of cost management system mainly includes the following several aspects: "the full cost method" to "manufacturing cost method"; the establishment of bad debt reserve system; adjust the part of the costs, expenses of the project. In addition, in order to creditors and managers, investors, government departments, design the index system can reflect the enterprise debt paying ability, operating ability and profit ability.

\section{EXISTING IN THE FINANCIAL MANAGEMENT OF CONSTRUCTION ENTERPRISES PROBLEMS}

\subsection{The Law, Not Through the Chapter}

At present, the construction enterprises in the fierce competition, the system relatively chaotic, poor management of some enterprises, the production efficiency is low, the production quality is poor, a lot of enterprises accounting personnel in individual or small group interests, not truthfully reflect the management state of the enterprise, and engage in malpractices for selfish ends, to cover up the truth, causing enterprises failed to strictly comply with the relevant accounting system, causing serious confusion still exists in large accounts, the accounting basis work not through the chapter, abiding by the law.

\subsection{Heavy, Light Management Accounting}

To some extent, some of the construction industry to do a good job of accounting personnel as the scope of their duties, such as accounting, accounts and reimbursement, contact with other departments and with less, while on the yield, output value, sales, costs, profits and other aspects of the data to provide more information, but how to efficient use of 
funds, reduce the cost the cost, improve the profitability of enterprises such as deep management problem is less, which cannot effectively play the whole efficiency of the enterprise, improve enterprise management level.

\subsection{Accounting Methods are Too Simple, Accounting Supervision}

The accounting method of accounting personnel in the construction industry is too simple, but also ignored the accounting supervision, accounting information distortion caused by a large number of. In addition to the full and effective use of modern means of accounting, the accounting information, not to the enterprise business supervision and control and the analysis of economic decision to provide a very good help, directly affects the accuracy of accounting information, timeliness, comprehensiveness and sharing.

\subsection{Financial Institutions are Not Perfect}

The construction industry accounting institutions are not perfect, the main provider of the following points: now some construction enterprises in the setting of accounting institutions at the same time, ignoring the organization of financial management functions; some enterprises accounting work entrusted to the accounting firm, seriously neglected the role of financial management in enterprise management in the enterprise accounting; and some institutions are not perfect, the insufficiency of professional staff, quality is not high, the staff and the implementation of post responsibility system is not clear enough, the lack of effective internal management system and the accounting supervision system.

\subsection{Lack of Attention to the Financial Management}

The construction enterprise management has not fully aware of the financial management function and its important role in enterprise management, and lack of modern financial management consciousness and advanced science. Due to the construction of enterprise mobility, the production cycle is long, broad and other characteristics, contents and steps of financial management of construction enterprises and other enterprises, which involve a number of steps. The influence of the traditional management ideas, some of our managers, especially the state-owned construction enterprise management on financial management was lack of knowledge, so that more parts of the production and operation activities of loopholes, reduce the operating level of construction enterprise, and bring immeasurable losses to the enterprise.

\subsection{The Lack of Advanced Scientific Methods}

The enterprise basic management is weak, the financial supervision and control is not in place, the business cost is too high, serious impact on the improvement of economic efficiency of enterprises. Due to the increasingly fierce market competition, a project, from the information obtained to the signing of the contract, and finally to the performance of the contract, ranging from a few months to several years, investment, human, financial, material resources is more and more big. The cost of doing business has become a heavy burden on enterprises.

\subsection{Enterprise Funds Management is Not Strict}

The debt cannot be timely cleaning, affect the authenticity of the enterprise assets and profit and loss. The funds cannot be recovered in time, turnover is slow, cannot guarantee the normal production and business activities of enterprises. Behind the project settlement, revenue recognition based on inadequate, resulting in accounts receivable is not real, effective control of the creditor's rights of enterprises. For many years to clean up the accounts receivable and prepaid subcontracting long-term losses, seriously affect the authenticity of the enterprise assets and profit and loss. "Hidden losses" and "potential profit" phenomenon occurs frequently, it is difficult to see the actual financial situation of the enterprise or project from the report.

\subsection{Enterprise Management and Accounting Personnel Management Level of Quality to be Improved}

Financial accounting staff almost does not participate in the management of enterprises, only "accounting, accounts, accounting, financial sector financial management" is "regardless of financial supervision", just after summing up, can only be empty talk.

\subsection{The Construction of Corporate Tax Evasion Problem is More Prominent}

Some of the local construction enterprises tax awareness is not high, only in the tax inspection, checkup points, arrears problem is more serious; the construction enterprises in the field. After the end of the project, not timely pay taxes; in addition, due to the construction enterprises often project funds are not in place, the construction unit of the phenomena in materials and so on, which makes the invoice and pay taxes in time is often not timely.

\section{THE SPECIFIC MEASURES TO IMPROVE THE PROBLEM OF FINANCIAL MANAGEMENT OF CONSTRUCTION ENTERPRISES}

\subsection{To Strengthen the Financial Management, Improve Financial Management System}

With the establishment and gradual improvement of China's market economy, the traditional financial management means and methods will face new changes. The importance of financial management of construction enterprises has been more and more entrepreneurs and managers agree. Financial management plays a key role in the development of construction enterprises. We should pay more attention to the importance of financial management, strengthen financial management, financial management penetrates into every aspect of the corporate governance structure and organizational management, and establish before, during and after the event, a full range of financial supervision and control system. Not only must constantly update the concept of financial management, but also to stand on solid ground, multi-channel financial security defense by progressive, realize the legalization, scientific financial management. Based on cost, efficiency as the core, improves financial management level of enterprises, and lays a good foundation for enterprise management enterprise to participate in market competition. Consciousness is 
the action of the preamble, the construction enterprises should strengthen internal staff of financial management, financial management concept to all levels of the enterprise to establish financial risk awareness, brand new, the investment of enterprises to determine the reasonable, the concept of financial management from the upper layer leading to lower staff gradually, so that all employees are aware of the importance financial management in enterprise management, the construction enterprises should establish sound financial management system, so that all employees are rules, strengthen internal control, the implementation of cost management, innovation management system, strengthening the performance control, so as to enhance the overall level of the financial management of construction enterprises, enhance the enterprise competitive power, finally realizes the enterprise benefit maximization. Establish and improve the accounting system, and strictly enforced. The establishment of the system is relatively easy, but because of the special project, the strict implementation of the difficulty is relatively large, accounting personnel should give full play to their functions. For staff attendance record attendance to do every day, every day to do with precious materials delivery and warehouse registration number on the purchase requisition, registration number for general consumption, sand stone, every purchase registration number, every day before work on the inventory. The machinery and equipment, repair costs, fuel consumption and workload per device per day should be recorded, so that evaluation: the acceptance of outsourcing material should have the relevant departments, and to regulate the name of material in warehouse, in order to improve the efficiency of accounting and statistics; engineering quantity every day should be completed (Fig. 1). Perfecting the accounting system, strengthen the fund property management. Construction enterprises should improve the accounting mechanism; give full play to the role of accounting supervision of enterprise assets, the assets to the person in charge of the project. At the same time, these assets should be unified accounting by the Corporation, and not by the project internal accounting. Unified management of the fund can reduce the waste of funds, reduce the cost of the project, to make the enterprise more clearly their overall capital scale. Construction enterprises should strengthen the financial management of enterprise consciousness; make it clear the concept of the time value of money, to strengthen the management of cash, with no damage to business reputation as far as possible under the early harvest late payment interest income, in order to obtain as much as possible. For cash payment procedures must be strict management, reduce the waste of money. Construction enterprises should be a large proportion of accounts receivable of enterprises accounted for the overall capital, affecting the quality of assets of the enterprise is very important, so the construction enterprise should strengthen internal management of accounts receivable, regular analysis for bad debts, accounts receivable aging long, strengthen efforts to reduce debt, bad debt losses, causes the enterprise to obtain the maximum revenue. To strengthen the budget control of construction, the implementation of effective supervision. Enterprise accounting control effect of the quality of construction, often with the budget has a very important link, strengthen the budget management of construction enterprises is very important. For construction. For construction enterprise, budgetary control must be from two aspects, one is the corporate budget, including the financial budget and the investment budget. On the other hand, is a specific construction project budget. Its relationship to the enterprise profit, whether the project can be successfully implemented, the key must therefore be as the enterprise internal accounting work. Establish risk awareness, the establishment of an effective risk management system, a comprehensive prevention and control of financial risk and operational risk. In the aspect of improving the financial quality, mainly focus on the following three aspects: first, in the recruitment, should pay attention to choosing the right people, choose those who master the new accounting standards and skills, hardworking, enterprising spirit of the people to play the accounting work; second, in the work to strengthen the follow-up study of accounting personnel, timely grasp the accounting policies and methods the update, the accounting personnel can take the initiative to update the relevant knowledge; third, to strengthen the management of the assessment, management and evaluation of accounting personnel, to achieve the suspect not, employers do not suspect, found that the problem timely treatment.

\subsection{The Accounting Department Should be Involved in the Whole Process of Management}

The business activities of enterprises have always been under effective control. Clear the project Department of the economic responsibility, to achieve cash rewards and punishment. Enterprises as the decision-making of project cost management, should serve as a profit center role, the implementation of the target profit management, target cost and target profit to project department, formulate specific methods and measures of cost management, the signing of economic responsibility objectives and project department, make clear the responsibility and obligation, and supervision and inspection in the implementation of the project, to ensure the realization of profit. As a project of the control layer of cost management, cost should be served as the central role, the implementation of the target cost control, cost control plan, will be the responsibility of decomposition, strict examination and rewards and punishments, to ensure the smooth realization of the target cost (Fig. 2)

\subsection{Fund Management as the Core, Improve Debt Man- agement System}

Money is the commercial value of monetary form, is the enterprise survival and development, is the fundamental guarantee of the enterprise production and management activities. Money management is the process of capital movement control, reasonable judgment through the analysis; we can predict and decision sciences. Strengthen the management of funds, should be timely recovery of funds, a rational allocation of resources, accelerate the capital turnover, improve the economic efficiency of enterprises. In order to guarantee the smooth progress of the funds management system must establish a sound debt management system. Establish a sound debt management system should first start from the source, strict contract signing, in strict accordance with the contract law; at the same time to 


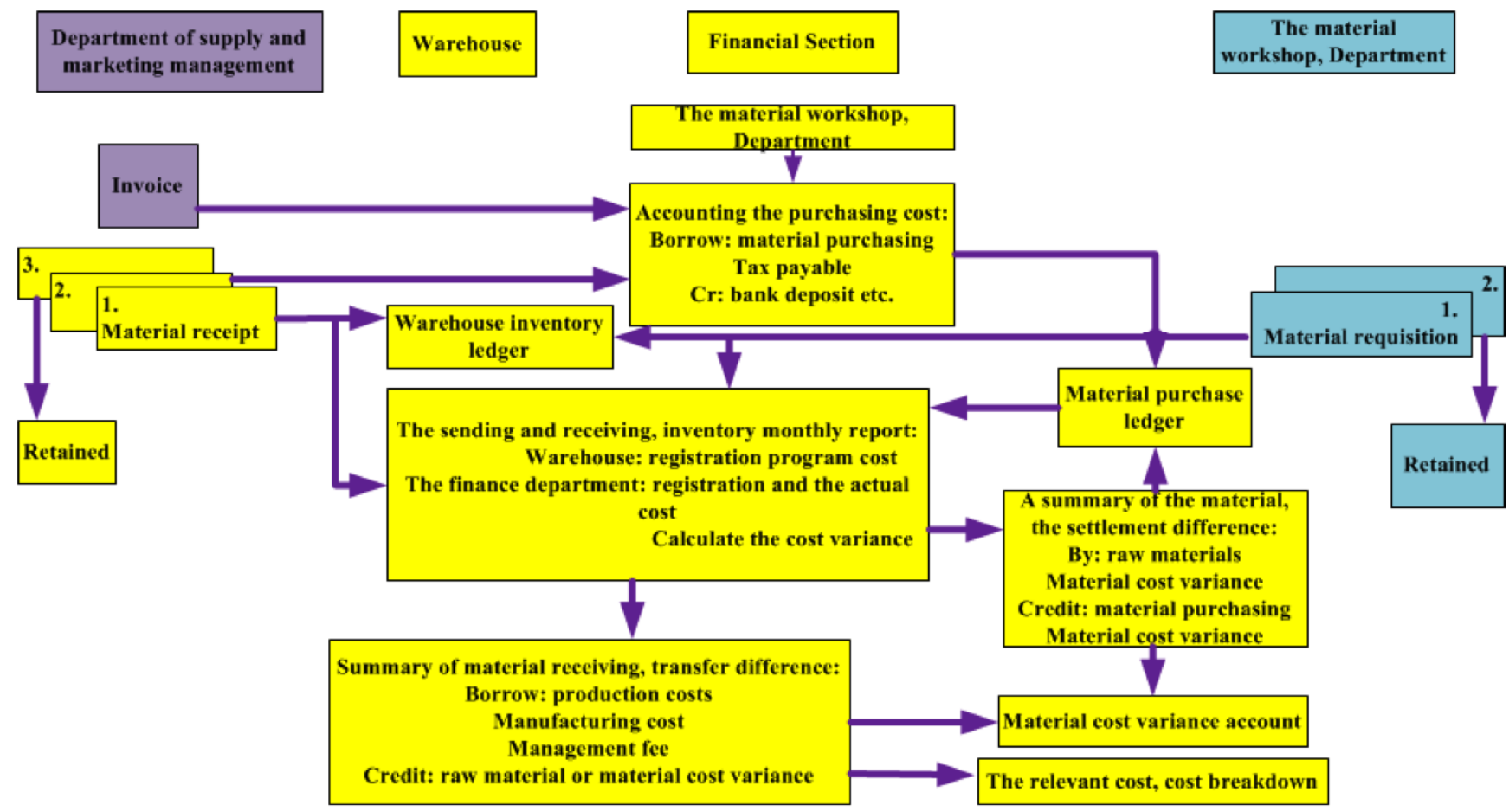

Fig. (1). Flow chart of material accounting.

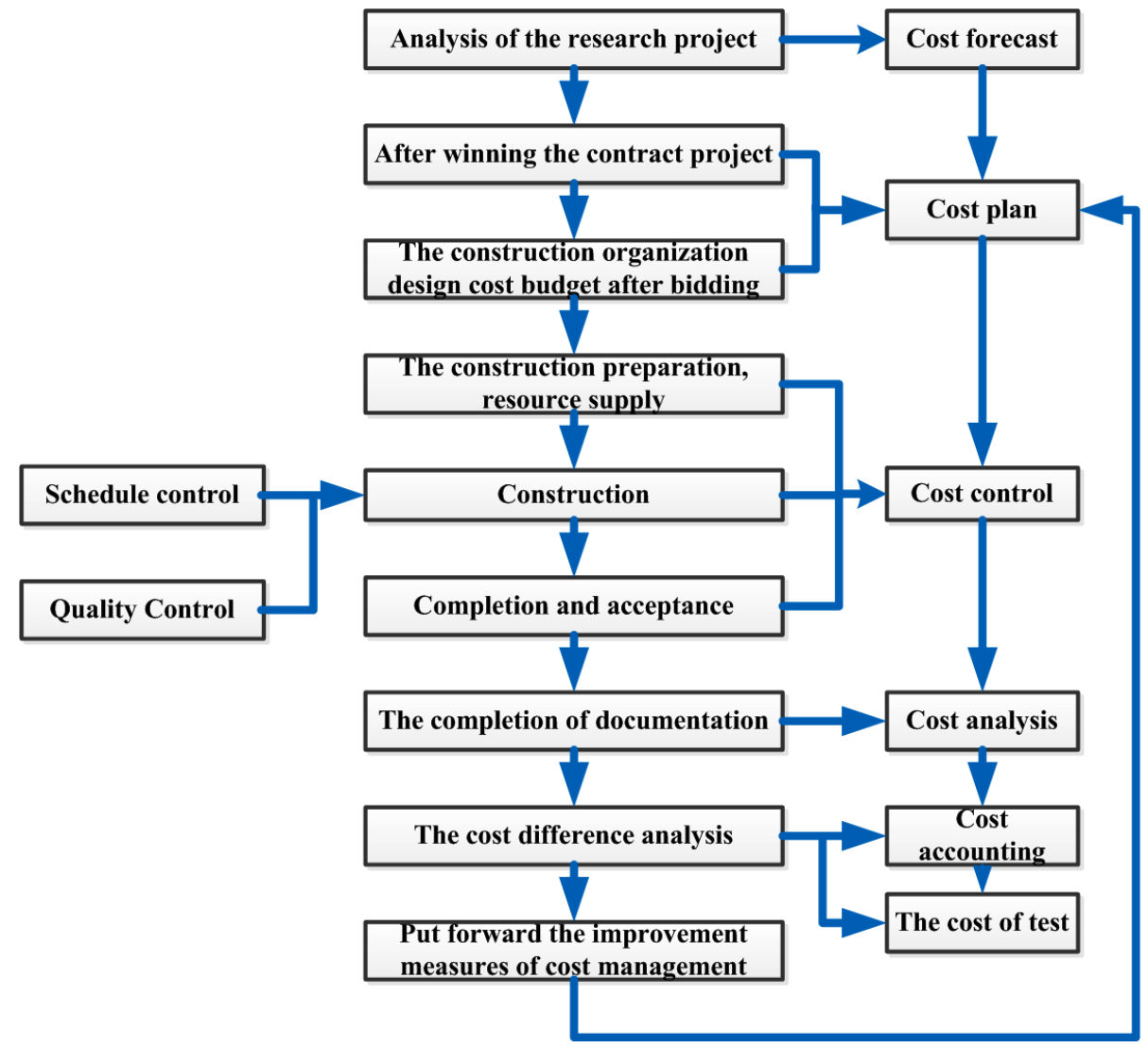

Fig. (2). Project cost management flow chart.

fulfill the terms of the contract to ensure that the rights under the contract. Secondly, to plan and control strictly in the construction process, to deepen the middle settlement, strengthen the completion of final accounts, keep accounts for projects of an enterprise is always in a range of control. Thirdly, to regularly check the accounts receivable with Party A, increased collection efforts and adopt feasible collection measures (Fig. 3). 


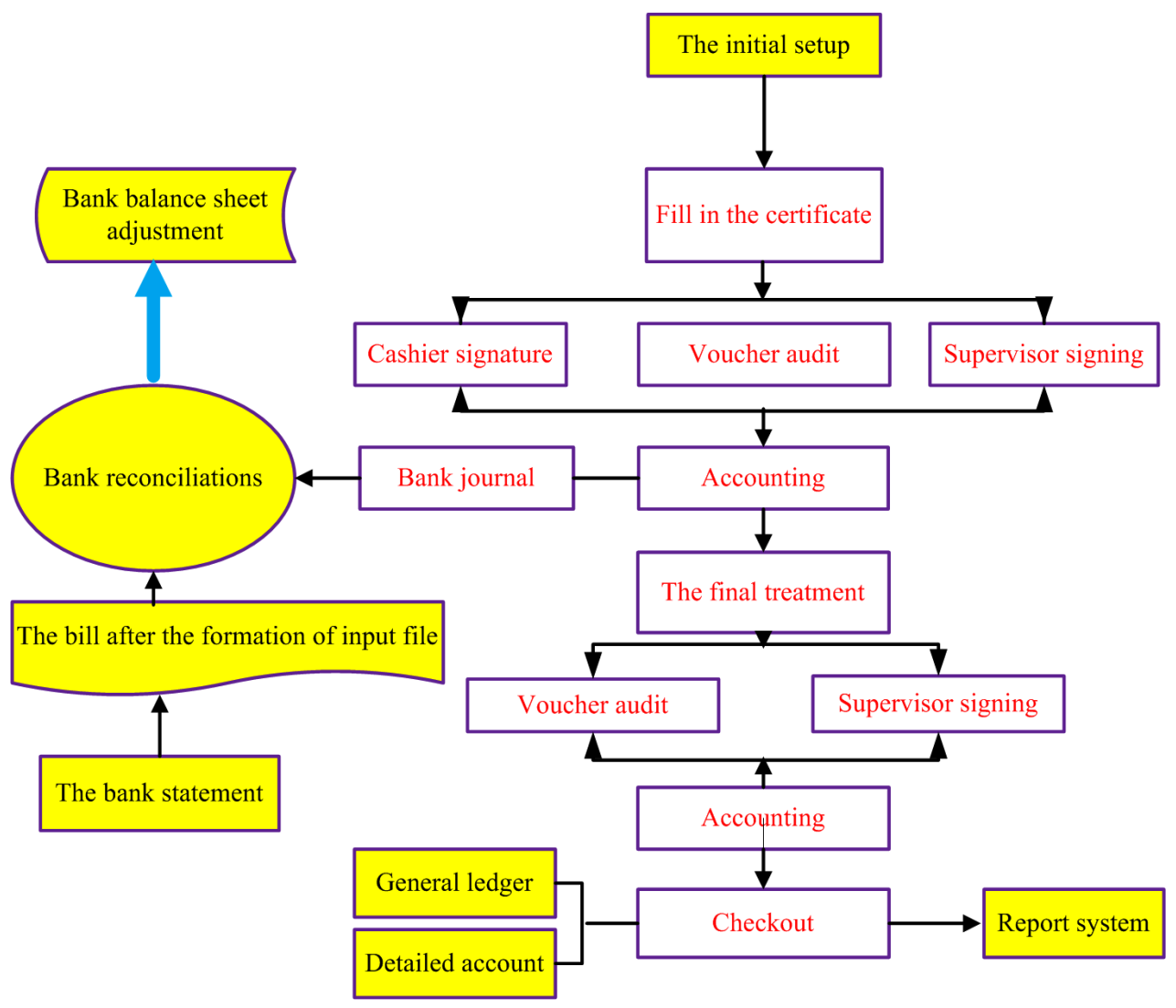

Fig. (3). Debt accounts registration.

\subsection{Hold and Revitalize the Enterprise Assets as a Whole, so That the Assets of the Enterprise Chain and Capital Chain Can Run Well.}

As a construction enterprise, the project of fixed assets and other assets occupy a larger proportion of the. At present, underwritten construction and engineering arrears recovery is two knives plagued the construction enterprise. Therefore, in addition to strictly regulate the construction business underwritten construction, make great efforts to clear arrears, if necessary, to use legal means to speak, but also the use of a good grasp of the proportion of assets and funds as a whole, as far as possible to reduce the use of risk capital and loans, the removal of funds and assets coordination problems bring enterprise risk fundamentally.

\section{CONCLUSION}

The financial and accounting management plays an important role in the specification, the comprehensive construction enterprise's development, financial and accounting management work of science can make construction enterprises in a timely manner to avoid the risk, accurately grasp the market opportunity, make the rapid reaction to market regulation, maximum growth and help the enterprise to realize the economic benefits, sowed only have a sound mechanism, strengthen enterprise management, improve the management level of the construction of financial accounting in order to ultimately make the construction units to achieve a comprehensive and sustainable development with strong competition trend.

\section{CONFLICT OF INTEREST}

The author confirms that this article content has no conflict of interest.

\section{ACKNOWLEDGEMENTS}

Declared none.

\section{REFERENCES}

[1] Y. Huang, "The countermeasures to solve the problems existing in the financial management of construction enterprises," Accounting Communications, vol. 4, 2007.

[2] X. Li, "Problems and countermeasures of financial management of construction enterprises," Friends of Accounting, vol. 9, 2009.

[3] Y. Tao, "The effective way to strengthen the financial management of construction enterprises," The Modern Economic Information, vol. 13, 2009.

[4] G. Zhao, "Problems and countermeasures of financial management of construction enterprises in the construction," Shanxi, vol. 27, 2009

[5] Q. Wu, "Thinking about the project management of construction enterprises," The western Accounting, vol. 2, 2010.

[6] C. Zhang, "How to Do the project financial management of construction enterprises," Accounting Monthly, vol. 2, 2010.

[7] X. Guan, "How to strengthen liquidity management in construction enterprises," The Enterprise of Science and Technology and the Development of, vol. 22, 2010 .

[8] G. Yao, "Thinking about the construction enterprise financial management," Xinjiang Economy, vol. 9, 2009.

[9] J. Yang, "Discussion on several problems of the construction of enterprise financial management in our country," The Modern Commercial, vol. 17, 2010.

[10] C. Zong, "To strengthen the financial management of construction enterprises to improve the competitiveness of construction enter- 
prises," The Management of Small and Medium-Sized Enterprises of Science and Technology, vol. 22, 2009.

[11] S. Zheng, "Internal control and accounting information quality," Journal of Dongbei University of Finance and Economics, vol. 03, 2003.

[12] L. Su, "The financial management and supervision of the construction project," Audit in Guangdong, vol. 05, 2003.
[13] H. Yang, The Financial supervision is the basic construction project "housekeeper", Economy, vol. 03, 2009.

[14] X. Xing, "Discussion on strengthening the basic construction project financial management and supervision issues," The Economic Division in, vol. 03, 2008

[15] S. Sun, "Strengthen enterprise financial management of basic construction project," Metallurgical Accounting, vol. 04, 2009.

Received: June 10, 2015

Revised: July 29, 2015

Accepted: August 15, 2015

(C) Yuqi Feng; Licensee Bentham Open.

This is an open access article licensed under the terms of the (https://creativecommons.org/licenses/by/4.0/legalcode), which permits unrestricted, noncommercial use, distribution and reproduction in any medium, provided the work is properly cited. 